\title{
Socio-Linguistic Referential Construction of Leaders in Kenya's 2008 Post-Consultation Discourse: Coalition Governance in Nascent Democracies
}

\author{
Margaret N. Barasa \\ Kisii University \\ Vicky Khasandi Telewa \\ Laikipia University \\ Jacinta M. Ndambuki \\ Laikipia University
}

\begin{abstract}
The general objective of this research was to gain understanding of the discursive referential construction. The paper aimed to enhance the existing studies on political discourse by investigating referential strategies used to institutionalise ideologies in coalition governments in nascent democracies. The objective of the study was to define referential strategies employed by Mwai Kibaki and Raila Odinga as principals in Kenya's 2008 coalition government and to construct and negotiate their ideological perspectives in governance. Four written texts were purposively sampled and accessed from the electronic data searches. The study was anchored on Critical Discourse Analysis approach. The results indicated that linguistic choices are ideologically and politically motivated in a consistent process of representation.
\end{abstract}

Key Words: Referential Strategies, Kenya, 2007 Post-election Discourse, Critical Discourse Analysis

\section{INTRODUCTION}

The National Accord and Reconciliation Act (2008) sanctioned the existence of the 2007 Grand Coalition government in Kenya. The Accord was anchored in the Portfolio Balance on the basis of power-sharing between the main parties viz: the Party of National Unity (PNU) and the Orange Democratic Movement (ODM). Mwai Kibaki was the former President holding the term from 2002 to 2007 in the then National Rainbow Coalition Government (NARC) while Raila Odinga was a cabinet Minister in the same NARC Government. The NARC coalition was the one which took over power from former President Daniel Toroitich Arap Moi. However, later, Raila Odinga broke away from the NARC Government due to misunderstanding over the Memorundum of Understanding (MoU) which according to Raila Odinga, was not honoured by Mwai Kibaki. It should be noted that before the formation of the Grand Coalition Government in Kenya in 2008, the earlier types of government were firstly, single party government (from 1963 to 1992), followed by multi-party government in the 1990s and a coalition government in 2002 (which also collapsed).

More importantly, the main aim of this study is an attempt to investigate how the two principals employed referential strategies to negotiate contentious issues of national concern and specifically, the Portfolio Balance (PB) and in one way or another sustaining the agreement. 
Discursive strategies are systematic ways of using language located at different levels of linguistic organization and complexity. Reisigl and Wodak (2001:44-85) distinguish five different strategies, namely: nomination/referential, Predicational strategy, perspectivation, argumentation, and intensifying/ mitigation strategy to bring out strategies of Self and Other presentation. The strategies of Self and Other presentation, described by Reisigl and Wodak (2001) when applied to the analysis of discriminatory, racist and stereotypical discourse generally try to delineate the scheme of analysing discursive strategies which contribute to the positive self and negative other presentation. Referential strategies, the focus of this paper, are linguistic tools with which persons and groups are identified (Reisigl \& Wodak 2001). They encompass the linguistic tools via which individuals and groups are named and referred to (Richardson 2007).

Analyzing these strategies is based on three assumptions: referring to social actors in a certain way is a matter of choice (Reisigl \& Wodak 2001), the way social actors are referred to carries value judgements (Richardson, 2007) and referential strategies "establish coherence relations with the way that other social actors are referred to and represented" (Richardson 2007: 50). Referential strategies function as a 'basis for the argumentation schemes of the text' (Reisigl \& Wodak 2009, 114); they are taken-for- granted starting points for argumentation. In other words, categorizing social actors via nominations is introduced as given and shared background information which conceals to a large extent the political and ideological interests served by this categorization. Ideologies conceal the way the socio-political world really works, camouflaging who most gains and who most loses from particular practices and programmes (Sloterdijk, 2003). Ideologies may not only control what we speak or write about, but also how we do so. Most theorists agree that there is no single definition of ideology as the term encompasses many different meanings and functions. Oktar (2001:314) defines ideology as "...presentations of who we are, what we stand for, what our values are and what our relationships with others are." This is particularly useful for this study and through referential strategies aims to reveal the role ideology plays in the formation of US and THEM groups in society. This study paid attention to how language is used to exploit this division and make the two leaders belong. Fairclough (2003: 18) state that ideologies “...are representations of aspects of the world which contribute to establishing and maintaining relations of power, domination and exploitation." Reisigl and Wodak's (2001) strategy of nomination, was used to tease out the ideological positioning in the texts. Fairclough (1989) says that, how the political voices are structured in relation to each other- which for example, tend to have the last word, will reveal who is exerting power. Therefore, texts are often sites of struggle in that they show traces of differing discourses and ideologies all contending and struggling for dominance.

Within texts, the analysis of how social actors are nominated can be valuable in understanding how their representations are used across texts. Social actors can be nominated through use of their name, which may also include additional honorific titles, such as Honourable or Sir. In addition, within the social actor network there are two key types of categorization for defining social actors: functionalization and identification (Van Leeuwen, 2008: 42-45). Van Leeuwen (2008: 43) states that the English language allows speakers to make a choice between functionalization and identification and that the implementation of this choice in discourse is of critical importance in discourse analysis for understanding the ways in which identity can be shaped throughout a text. Functionalization manifests when social actors are referenced through activities and the things they do, such as occupations or roles. Because of this type of usage, government officials are always functionalized and so are Kibaki and Odinga. Identification transpires when social actors are designated not through what they do, but in 
terms of what they inexorably are. Additionally, identification can be divided into three types: classification, relational identification and physical identification. Classification refers to the ways in which social actors are defined by the differentialities between classes of people within a given society or institution. Relational identification refers to social actors via their personal relationships, kinship or work relations. Physical identification refers to social actors via their physical characteristics to uniquely distinguish them within a specific context.

Available literature indicate that little attention has been paid on the use of language by the coalition leaders as a way of resolving contentious issues of national concern. This is informed by the fact that language interrogates power and ideology. This paper examines referential strategies in the discourse of Kibaki and Odinga as principals in Kenya's 2008 Coalition Government negotiation for Portfolio Balance with a view to generalize the linguistic and discursive strategies used in this representation, and try to work out the political relevance of these nominations in the context of a grand coalition government in Kenya. This study thus sought to identify the referential strategies utilized by Kibaki and Odinga and determine how the nominations are used to construct their images.

\section{METHODOLOGY}

The study adopted a descriptive research design to investigate the referential strategies of Kibaki and Odinga. The data gathered for the purposes of this study were extracted from the former President's and former Prime Minister's website and the Public Communications Office of the Government Spokesperson. The discourses in texts focused on the instance of the Formation of the Grand Coalition Government in Kenya in 2008, specifically the Portfolio Balance. Permission to use these texts for this research was sought and granted by the National Council for Science Technology and Innovation. In total, four texts were purposively sampled for a Critical Discourse Analysis. Purposive sampling was used to sample four texts from the post-election negotiation discourse using electronic data searches. In addition, the National Accord (2008) was also considered as a related text to the four aforementioned texts. Therefore, in this study, all the four texts including the National Accord were referred to as the post-election consultation negotiation texts.

This study was anchored in the theory of Critical Discourse Analysis with major theorists as Fairclough $(1989,2003)$ and Reisigl and Wodak (2001). Since CDA sees discourse as both produced and shaped by ideology, it stresses the essential linguistic characteristics of social relationships, structures and the power distributed among them. Therefore the use of Fairclough's three levels: text, discursive practice and social practice. The data was modified by numbering the sentences for easier referencing during analysis. Thereafter, referential strategies were analysed based Fairclough (1989, 2003) and Reisigl and Wodak (2001) Discourse Historical Approach (DHA). One principle of DHA is that numerous genres and spaces as well as intertextual and interdiscursive relationships are studied. The historical orientation permits the reconstruction of how recontextualisation functions as an important process linking texts and discourses intertextually and interdiscursively over time. This made explicit the nature or progress of the negotiations and the broader intertextual meaning relations and ideologies that connected the texts. In analysing the four texts under study, it was possible to observe the shifting social and historical situation that was recreated as the negotiations unfolded.

CDA is both theory and method. It examines the role of discourse in the social constitution of power relations and structures of domination in contemporary society hence the use of the theory in this study. In this study, CDA was used because it brings out the social issues that are 
a characteristic of the country's political conflicts. CDA is suitable for investigating why the participants say what they say and how they say it and the underlying intentions. It also helps reveal to what extent the social actors' statements, claims, assertions, and denials are the product of their own individual and social political ideologies and how these are negotiated when confronted with opposition. It is a useful tool in the analysis of the texts because it allows for the realization of the interdependency of language and ideology, socio-cultural practices and socio-cultural politics. For CDA, language is not powerful on its own; it gains power through the use of powerful people who make use of it. In texts, discursive differences are negotiated and governed by differences in power which are themselves in part encoded in and determined by discourse and genre.

\section{Referential/ Nomination Strategies}

\section{RESULTS AND DISCUSSION}

These are strategies that identify how persons are named or referred to linguistically in discourse and in so doing discursively represented and positioned as, for example, part of ingroups and/or out-groups. The devices used for this strategy mostly fall into membership categorization e.g using biological, naturalizing and depersonalizing metaphors or using synecdoche (totum pro pars or pars pro toto respectively). The following Table 4.1 presents a summary of this strategy as employed by the two leaders in the four texts under study.

The main social actors in the four texts under study are Kibaki and Odinga. Referential strategy of Genericisation is used by both Kibaki and Odinga. Genericisation either identifies classes particular to that group leading to inclusiveness/legitimization or identifies classes of the Other leading delegitimization. Kibaki and Odinga speak in their roles as the leaders of their respective political parties, hence the referential terms of Party of National Unity (PNU) for Kibaki and the Orange Democratic Movement (ODM) for Odinga. These positions institutionally entitles them to put forward their case about the interests of their parties and themselves. This was made explicit by the use of the referential strategies of pronouns 'I' 'we' and 'our' as forms of pronominalization.

\section{Raila Odinga says:}

It is becoming clear to our party that your side is reluctant to honour the spirit and principles of the National Accord and Reconciliation.

I therefore wish to let you know that the following issues must be resolved in the course of our further consultations on the formation of the Government.

The use of "our" shows collective decision in the quest for the equal power sharing between the Orange Democratic Movement (ODM) and the Party of National Unity (PNU). Whereas "I" indicates individual responsibility of Odinga to ensure that he and his party ODM gets its share of power as agreed upon in the National Accord.

\section{Kibaki in response to Odinga's quest says:}

I have accorded this matter my personal attention and highest priority throughout.

I realize the importance of this matter to all Kenyans and the anxiety it is causing and it was my personal desire to have this matter concluded today. 
Yesterday, I and Hon. Raila Odinga promised in a joint statement that we would convene today to have the matter concluded.

This is because we were of the view that the remaining few matters relating to the formation of the cabinet could have been resolved today.

The use of the pronominal "I" construct Kibaki as taking charge of the situation as the president to make sure that the portfolio stalemate is resolved. In addition the use of "we" is a show of collective decision between him and Odinga to resolve the issue. Therefore the inclusive use of "we" and "us" and "our" as forms of Genericisation indicate collectivism ideology which show that the principals are operating as a coalition. Further the use of "I" show individual responsibility and commitment and it was used by Kibaki and Odinga as a Genericisation strategy to serve the ideology of legitimating self and delegitimatizing the Other.

Relational identification is another significant referential strategy used by both Kibaki and Odinga. Kibaki constantly refers to Odinga using the official nomination "Honourable" and Generecisation "the ODM". Further, it was observed that whereas Odinga used functionalization to address Kibaki, on the contrary, Kibaki was evasive in addressing Raila Odinga by use of the same throughout his discourse, and instead resulted in using official nomination and Generecisation. This difference is significant because Odinga's discourse is denied involvement in the power sharing deal as an equal partner leaving Kibaki in control of the message as the president and thus the sole decision-maker.

\section{Kibaki states:}

The ODM should understand clearly with no uncertain terms that the Executive Authority of the state is vested in the President. The assumption that these powers are irrelevant as a result of the National Accord and Reconciliation Act is irresponsible, reckless and distortion of the facts and the law.

Greater progress will be made through working together as coalition partners and not through confrontational public shows. ODM should now move from confrontational and activist politics of the opposition into responsible politics of governance.

I invite Hon. Raila Odinga to engage constructively so that we can conclude the formation of the government.

Evasiveness is used by Kibaki to background Odinga's quest for equal sharing of power. This enables him to delineate Odinga from political involvement as a Prime Minister. The backgrounding of Odinga as the premier enables Kibaki to indirectly attack Odinga's belief in confrontational politics which are a characteristic of the opposition and thus do not befit Odinga as a Prime Minister. Such representations that omit his status as the Prime Minister are clearly employed as an attempt to entwine Odinga within the representations of a political loser, hungry for power.

On the other hand, Odinga refers to Kibaki through functionalization using the term "the President" and "excellency".

\section{Odinga says:}

We have always acted in good faith and conveyed to your Excellency that the Grand Coalition would be one government.... 
The President and I promised the nation yesterday that we would finalize arrangements for the Grand Coalition government, including the naming of the Cabinet.

The National Accord and Reconciliation Act is already in force. It must be understood that ODM and PNU are equal partners in the Grand Coalition.

Odinga utilizes functionalization as an acknowledgment of Kibaki's office. Though his function is suppressed by Kibaki not making reference to his public office, Odinga utilizes functionalization to depict Kibaki as one who was reluctant to share power despite the official enactment of the National Accord which sanctioned the power sharing deal. The functional nomination juxtaposed with the personal nomination of "I", puts Odinga to a similar rank with Kibaki thus equal partnership.

Functionalization is also manifested in the roles social actors play. Odinga utilizes generecisation and specification as functional identities of social actors. For instance, the social actor "Ambassador Muthaura" is functionally correlated with the Party of National Unity (PNU) side and the president to signify the powers of the former as the Head of the Civil Service and Secretary to the Cabinet then. Ambassador Muthaura was charged with supervising and coordinating the ministers, a role which was to be relinquished to the Prime Minister upon the sanctioning of the Grand Coalition government. However, this seems not to be the case as Odinga states thus:

The following day, 3rd April, President Kibaki and I met for two hours and made numerous concrete agreements on Portfolio balance that I have just mentioned, which enabled both of us to say publicly that the Cabinet would be announced yesterday (Sunday).

On Saturday, I received from Ambassador Muthaura a letter unilaterally indicating that the cabinet to be announced would be formed on the basis of an enclosed list of ministries and their allocations that we had rejected on 2nd April! The agreements we reached in our 3rd April meeting were nowhere to be seen. We were therefore unable to reach any agreement in the six hours of talks yesterday.

Today, in response to a letter I had written to President Kibaki, we received a reply from Ambassador Muthaura's side reneging on our previous agreements, as well as the spirit and the letter of the Accord. In PNU's interpretation, the Constitution grants the President exclusive executive power to run this country on his own, and that these powers supersede all the provisions of the Accord.

Odinga utilizes the nomination of Ambassador Muthaura to construct Kibaki and his party as representing and propagating single party dominance ideology irrespective of the Grand Coalition government being in place. Further the role of the premier as illustrated in Clause 4 (National Accord 2008) which lays down the functions of the PM among which is co-ordination and supervision of the affairs and execution of functions of government by various ministries and appointment of Ministers and Assistant Ministers in the coalition government was still being done by Ambassador Muthaura. Being the closest ally of former President Kibaki, Muthaura could have indirectly been involved in making decisions for the former President as concerns the formation of the cabinet. The presupposition is that Kibaki as the president then was unilaterally making decisions and monopolizing power and disregarding the spirit of the National Accord. 
Moreover, relational identification is utilized by Odinga to construct the social actor "George Saitoti" as another close political ally of Kibaki. Odinaga says:

... We accepted PNU's insistence on a bloated 40 member cabinet. On 1st April, President Kibaki's emissary, Hon. George Saitoti gave me a proposed list of 40 ministries and how they should be divided.

... in response to a letter I had written to President Kibaki, we received a reply from Ambassador Muthaura side reneging on our previous agreements, as well as the spirit and the letter of the Accord.

By utilizing the nomination of George Saitoti, Odinga presupposes breach of protocol by Kibaki and dissemination of single party dominance.

Impersonalization by Abstraction is another significant referential strategy utilised by both Odinga and Kibaki. Abstraction involves utilizing social actors via a quality that is assigned to them by and in the representation. For instance, Odinga employs the synecdoche "Grand Coalition" as an abstraction which serves to remind Kibaki about the agreement of power sharing.

The failure to form the Grand Coalition Government is in fact a continuing breach of the Act and the constitution.

We have always acted in good faith and conveyed to your Excellency that the Grand Coalition would be one government. The positions PNU is taking claim to imply that we are forming a government with two cabinets.

On the contrary, this is a Grand Coalition of two equal partners sharing executive power on a 50-50 basis.

Odinga uses abstraction to show to construct an identity of a change from single party dominance to a coalition where power is shared. On the contrary, Kibaki also uses the expression "this matter" as a synecdoche that backgrounds the formation of the Grand Coalition government. Kibaki says:

I have accorded this matter my personal attention and highest priority throughout.

I realize the importance of this matter to all Kenyans and the anxiety it is causing and it was my personal desire to have this matter concluded today.

Yesterday, I and Hon. Raila Odinga promised in a joint statement that we would convene today to have the matter concluded.

The backgrounding by Kibaki presupposes the single party ideology. Therefore, Kibaki uses abstractions to represent his believe in single party dominance, whereas Odinga utilizes impersonalization through abstraction to construct an identity within the texts that is similar to his goal of forming the Grand Coalition Government. Odinga also accounts for his unique status as the initiator of change by the use of the synecdoche "Grand coalition government" to explain what Kibaki is not and thereby define what he, Odinga is. 


\section{Odinga says:}

Our party is deeply concerned that the stalemate over the formation of the Grand Coalition Government is increasing uncertainty and anxiety in the country. It is escalating the mistrust that we as leaders were expected to eliminate by the establishment of the Grand Coalition.

The National Accord and Reconciliation Act is already in force. It must be understood that ODM and PNU are equal partners in the Grand Coalition. ...

With cries of jubilation and Happy New Years, (sic) Kenyans on 28th February began to breathe freely again as the National Accord brokered by Mr. Kofi Annan was signed by President Kibaki and myself. The terror and fear they had been living under the hands of mobs, militias and government forces was finally over. A few weeks later, Parliament unanimously entrenched the Accord into the Constitution and Laws of Kenya.

But since then Kenyans have observed with growing dismay and anxiety that not a single concrete agreement has been achieved on any aspect of the new coalition government. Our nation is a drift and without direction, and with each passing day, our problems are mounting.

To overcome this terrible impasse and another looming crisis, our side has gone many extra miles and made an extraordinary number of concessions. Against the strong wishes of our supporters and indeed of all Kenyans, we accepted PNU's insistence on a bloated 40 member Cabinet. I agreed also to cede some of the most crucial ministries.... as Finance, Defense, Internal Security and Justice and Constitutional Affairs.

Thus the symbol "Grand coalition government" is employed in place of Odinga. By focusing on what he as change represents, Odinga is able to make his intended actions seem more accepted and not subject to scrutiny.

Having identified the participant positions and roles, it is worth mentioning that a clear demarcation can be observed between US and THEM which depended on the point of view of the speakers. Furthermore, the choices in the pronoun use in nominalization suggest an US versus THEM representation. US/WE is associated with positive elements and THEM/THEY with negative elements.

The data revealed that Mwai Kibaki uses similar pronominalization strategies as those of Odinga to delegitimize the actions of the Other and legitimize those of self. However, it can also be observed that while Raila Odinga uses the pronoun "we" more often, Kibaki employs the pronoun "I". This can be analysed to indicate that Kibaki asserts his authority and personal involvement in the use of the pronoun "I" while Odinga may be falling back to his party to seek for support and also spread responsibility in relation to the decisions so far made on the issue of the Portfolio Balance.

In summary, the referential strategies of Odinga about PNU party confirm the fact that during the formation of the Grand Coalition Government, political parties controlled their leaders' decisions and even demanded accountability from them. Furthermore, a political party moulds the leaders who in turn are expected to fight for the welfare of its members (Masime and Oesterdiekhoff (2010). This appears to be the reason why the former President could not overlook the push from his PNU party about the formation of the cabinet. This is not restricted to PNU party but also to ODM party. The use of the pronominals "we" and "our" attest to the 
inclusiveness of the parties. In a similar way, the referential strategies used by Kibaki reveal the division between "US" and "THEM" which is strongly exploited as a means to unite the PNU side. For instance, Kibaki states:

Since the signing of the Accord, the Government Coalition has embraced the Spirit of Partnership with ODM and most of the initiatives that have been taken, especially in regard to the Accord have been undertaken on consultative basis between the two parties (2PB 4.4.)

Kibaki also mentions the allegations laid against the Government Coalition as:

Government Coalition has been surprised by the statement made by ODM in regard to the implementation of the National Accord Act and the related Constitutional Amendment. The ODM in their statement allege that the Government Coalition is dragging its feet in the formation of the cabinet (1PB 4.4).

It is expected that the PNU had to legitimate its actions and in doing so, delegitimate those of the ODM. Therefore, the representation of the Other group (PNU) is maximized by emphasizing on its negative activities and the speaker constructs them using expressions such as untrustworthy, tardy, irresponsible, reckless, distorts the law, and engage in activist politics.

\section{CONCLUSION}

From the findings of this study, it is concluded that Mwai Kibaki and Raila Odinga, employed referential strategies that were void of innuendos as they negotiated on the issue of Portfolio Balance. In addition, the language as a negotiating tool was mitigated and highly restrained in terms of expressions that could be classified as forms of hate speech. In addition, the two leaders used language that was mindful of the other and revealed rational arguments that could be justified using the legal documents, particularly, the National Accord and the Constitution of Kenya (2010), persuasive language encoding tolerance and optimism and also reassurance for continued political support notwithstanding the competition for power. A conclusion can therefore be made that despite a contested, competitive relationship between Mwai Kibaki and Raila Odinga, a respectful, reasonable, mindful, mitigated use of language during negotiations and as a result averted conflict leading to successful negotiations. This is also an indicator that possible future political differences between coalition partners would be reconciled amicably. It can therefore be concluded that positive use of language to negotiate political differences is important for the success of any coalition government. Further, with the formation of new coalition governments in Africa, for example, the signing of the Agreement between President Salva Kirr and his former Deputy President Dr. Machar, in the Republic of Southern Sudan, in February, 2014; the role of language as a medium through which power is appropriated, negotiated, deployed or distributed cannot be overemphasized.

\section{References}

Alfayez, H. (2009). Martin Luther King “I Have a Dream: Critical Discourse Analysis” King Saudi ESUniversity: Unpublished MA.

Chege, M. (2008). Kenya back from the Brink? Journal of Democracy 19 (4):125-39

Fairclough, N. (1989). Language and Power. New York: Longman Discourse Reassembled. London: Routledge, PP.284-326.

Kamalu, I. and Agangan, R. (2012). “A Critical Discourse Analysis of Goodluck Jonathan Declaration of Interest in the PDP Presidential Primaries". Ibadan: Covenant University

Masime, K. and Oesterdiekhoff, P. (2010). Institutionalizing Political Parties in Kenya.

Nairobi: Centre for Governance and Development and Friedrich Ebert Stiftung. 
Nyukuri, B. (1995). "Ethnicity, Nationalism and Democracy in Africa: The Dilemma of Sustainability." A paper read at UNESCO Seminar, 28-31 May 2009. Sports ground Kisumu

Oktar, L. (2001). 'The Ideological Organization of Representational Processes in the Presentation of US and THEM". Discourse and Society. Vol. 12(3):313-346

Orodho, A.J (2003). Essentials of Education and Social Science Research Methods. Nairobi: Masola Publishers.

Orwenjo, D. and Ogone, J. (Eds) (2010). Language and Politics in Africa: Contemporary Issues and Critical Perpectives. Cambridge: Cambridge Scholars Publishing.

Reisigl, M. and Wodak, R. (2001). “The Discourse Historical Approach (DHA)” In R.Wodak and M. Meyer (Eds), Methods of Critical Discourse Analysis, (2nd edn), London: Sage, 87-121.

Republic of Kenya: Public Communications Office of Government Spokesperson, Nairobi. 2008.

Sloterdijk, P. (2003). Critica de la razon Cinica. (Critical Discourse Analysis). Madrid: Siruela

Thompson, J.B. (1984). Studies in the Theory of Ideology. Cambridge: Polity Press

Waki Report (2007/2008). Post-Election Violence in Kenya: Nairobi

Zartman I. W. (1997). Introduction. In : Zartman . I. W., Governance as Conflict Management: Politics and Violence in West Africa. Washington: Brookings Institution Press. 